\title{
Sikap Motivasi dan Pengembangan Jiwa Kewirausahaan Studi Kasus Mahasiswa Politeknik Kridatama
}

\author{
Evi Selvi ${ }^{1}$, Dewi Untari ${ }^{2}$ \\ ${ }^{1}$ Universitas Singaperbangsa Karawang \\ Email : pulma8003@gmail.com \\ ${ }^{2}$ Politeknik Kridatama Bandung \\ Email: dew11untari@gmail.com
}

Cara Sitasi: Selvi, E., \& Untari, D. (2019). Sikap Motivasi dan Pengembangan Jiwa Kewirausahaan Studi Kasus Mahasiswa Politeknik Kridatama. Widya Cipta, 3(1), 51-60.

\begin{abstract}
This study discusses the motivation and development of entrepreneurial spirit Kridatama Polytechnic Bandung students request an understanding of entrepreneurship as a whole. The method used in this study is qualitative data which is presented in the form of words, not in the form of numbers, from this study are students of the third semester of the Entrepreneurship Course at Kridatama Polytechnic Bandung who gathered 98 students. The results of the discussion addressed that the Kridatama Polytechnic Bandung Students did not yet have the confidence needed and the development of entrepreneurial motivation. From the interviews of Kridatama Polytechnic students, they needed a lot of entrepreneurship training, entrepreneurship seminars and Bandung Kridatama Polytechnic students who still needed a lot of information for the development of entrepreneurial spirit. The Kridatama Polytechnic that has been formed comes from the first skills that shape mental attitudes, form superior personalities who are good at initiating and can coordinate their business activities.
\end{abstract}

Keywords: Attitude, Motivation, Entrepreneurship, Entrepreneurship Soul Development

\section{PENDAHULUAN}

Indonesia merupakan negara kepulauan terbesar di dunia yang memiliki kurang lebih 250 suku bangsa, dan tergolong sebagai negara Asia dengan jumlah penduduk sangat besar yaitu sekitar 262 juta jiwa. Jika penduduk di Indonesia dibina dan ditumbuhkan jiwa kewirausahaannya dengan baik, akan menjadi aset nasional yang handal dan mampu bersaing di pasar global. Apalagi kondisi tersebut didukung oleh sumber daya alam yang cukup dan beraneka ragam.Kondisi tersebut belum bisa sepenuhnya dijadikan sebagai modal pembangunan karena terbukti meskipun kemajuan pembangunan telah menghasilkan banyak tenaga terdidik, namun kondisinya belum sepenuhnya menggembirakan.

Secara faktual menurut versi World Economic Forum (WEF) peringkat Indonesia selalu berada jauh di bawah posisi Singapura yang hampir setiap tahunnya berada pada peringkat kedua (2) dunia atau pertama ASEAN.Daya saing versi WEF adalah daya saing suatu Negara/ekonomi, bukan daya saing suatu produk.Berikut fakta aktual versi WEF tersebut:

Tabel 1.

Peringkat Daya Saing Global (Global Competitiveness Index/GCI) Negara-Negara Anggota ASEAN Menurut Versi WorldEconomic Forum (WEF) Tahun 2016 dan 2017

\begin{tabular}{clccc}
\hline No. & Negara Anggota & $\begin{array}{c}\text { GCI } \\
2014-\end{array}$ & $\begin{array}{c}\text { GCI } \\
2015-\end{array}$ & $\begin{array}{c}\text { GCI } \\
2016- \\
2015\end{array}$ \\
& & 2016 & 2017 \\
\hline 1. & Singapura & 24 & 2 & 2 \\
2. & Malaysia & - & - & 25 \\
3. & Brunei Darussalam & 37 & 32 & 58 \\
4. & Thailand & 38 & 37 & 41 \\
5. & Indonesia & 59 & 47 & 57 \\
6. & Filipina & 70 & 56 & 60 \\
7. & Vietnam & 81 & 83 & 93 \\
8. & Laos & 88 & 90 & 89 \\
9. & Kamboja & 139 & - & - \\
10. & Myanmar &
\end{tabular}

Sumber:WEF 2015, 2016 dan 2017. 
Informasi data seperti di atas disebabkan oleh kurangnya jumlah wirausaha yang memadai.Padahal jiwa wirausahawan inilah yang nantinya diharapkan mampu mengelola faktor-faktor produksi yang akan menghasilkan barang dan jasa bermanfaat bagi masyarakat. Karena, hanya faktor produksi manusia yang mampu mengelola sumber daya atau faktor produksi lainnya.Tidaklah mudah untuk menciptakan lingkungan masyarakat yang memiliki jiwa wirausahaan. Di Indonesia ini, memang cukup banyak penduduk yang mendirikan usaha skala mikro dan kecil.Dari usaha mikro menjadi usaha kecil, dari usaha kecil menjadi usaha menengah dan dari usaha menengah menjadi usaha besar.Jika usaha naik maka tingkat kesejahteraan masyarakat pun bisa ikut ditingkatkan.

Program pembentukan jiwa kewirausahaan di Indonesia telah berlangsung cukup lama dilakukan oleh lembaga formal maupun non formal. Program pembentukan dan pengembangan jiwa kewirausahaan biasanya dilakukan secara mandiri maupun dengan kemitraan dan dukungan dana dari pemerintah atau lembaga-lembaga swasta yang mengalokasikan anggaran setiap tahun untuk program kewirausahaan terutama diperuntukkan untuk penduduk yang belum memiliki pekerjaan atau pengangguran.Namun, program-program pembentukan dan pengembangan tersebut belum cukup bisa mewujudkan banyak munculnya jiwajiwa kewirausahaan yang baru.Oleh karena itu, diperlukan suatu pengembangan sikap dan jiwa kewirausahaan ditingkat pendidikan tinggi.

Guna mengurangi jumlah pengangguran di tingkat perguruan tinggi khususnya Politeknik Kridatama Bandung.Kampus Politeknik Kridatama merupakan kampus swasta yang memiliki mahasiswa belum dan sudah bekerja.Mayoritas mahasiswa hanya mencari pekerjaan, bukan menciptakan lapangan pekerjaan.Mahasiswa Politeknik Kridatama Bandung harus bersaing dengan kampus-kampus besar dan ternama di wilayah Bandung dan sekitarnya.Oleh karena itu, mahasiswa Politeknik Kridatama Bandung memerlukan suatu pemahaman tentang kewirausahaan secara mendalam.Permasalahan yang sering dialami mahasiwa lulusan Politeknik Kridatama Bandung adalah sulitnya untuk memulai usaha dan mencari pekerjaan.Dikarenakan mahasiswa belum memiliki nyali kuat untuk berwirausaha dan persaingan kerja yang ketat. Sehingga diperlukan sikap dan motivasi untuk mengembangkan jiwa kewirausahaan mahasiwa Politeknik Kridatama Bandung agar mampu dan bangkit untuk berwirausaha dan bersaing menciptakan lapangan pekerjaan sendiri tanpa harus mencari pekerjaan yang persaingan dan kualifikasi dianggap berat bagi mahasiswa dan lulusan Politeknik Kridatama Bandung.

Menurut Nishanta (2008) Faktor internal berasal dari diri wirausahawan dapat berupa karakter sifat, maupun faktor sosio demografis, seperti umur, jenis kelamin, dan lain-lain yang dapat mempengaruhi perilaku kewirausahaan seseorang karena sikap dapat dipengaruhi oleh sifat yang ada dalam diri seseorang.Sifat tersebut dapat berorientasi pada perkembangan yang sangat diperlukan oleh seorang wirausahawan agar sukses memiliki usaha yang maju dan berkembang.

Sikap adalah reaksi dari individu seseorang yang masih tertutup terhadap suatu stimulus atau obyek Soekidjo N (2003).Newcomb dalam Notoatmodjo (2003) menyatakan bahwa sikap merupakan kesiapan atau kesediaan untuk bertindak, dan bukan merupakan pelaksanan motif tertentu. Sikap belum merupakan suatu tindakan atau aktifitas, akan tetapi adalah merupakan "pre-disposisi" tindakan atau perilaku dan merupakan reaksi tertutup, bukan merupakan reaksi terbuka.

Sikap adalah reaksi dari individu seseorang yang memihak / tidak memihak yang merupakan keteraturan tertentu dalam hal perasaan (afeksi), pemikiran (kognisi) dan predisposisi tindakan (konasi) seseorang terhadap suatu aspek di lingkungan sekitarnya Saifudin A, (2005).

Sikap (attitude) merupakan perasaan, pikiran, seseorang yang kurang lebih bersifat permanen mengenal suatu hal tertentu dalam lingkungannya.Sikap juga merupakan kesiapan mental seseorang atau emosional dari beberapa jenis tindakan pada sesuatu yang tepat. Selain itu dapat diartikan sebagai sesuatu yang dipelajari dan bagaimana individu bereaksi terhadap situasi dan menentukan apa yang dicari dalam kehidupan Rosmiati (2015)

Menurut Kamus Besar Bahasa Indonesia (KBBI), sikap merupakan perbuatan, perilaku, atau gerakgerik yang berdasarkan pada pendirian keyakinan dari pandangan hidup seseorang. Sikap dan perilaku sangat dipengaruhi oleh sifat dan watak yang dimiliki seseorang.Sifat dan watak yang baik berorientasi pada kemajuan yang dibutuhkan oleh seorang wirausahawan agar dapat berhasil.Maka dari itu seseorang ingin mencapai tujuannya, maka diperlukan sikap dan perilaku yang mendukung pada 
diri seorang wirausahawan.Seorang wirausaha harus bersikap terbuka pada pengalaman-pengalaman baru sehingga menjadi siap untuk merespon segala peluang, dan tanggap terhadap perubahan sosial misalnya dalam mengubah standar hidupnya.

Menurut Suharyadi (2007) bahwa sikap seorang wirausaha dapat dilihat dalam kegiatan sehari-hari, antara lain:

1. Disiplin, yaitu ketepatan komitmen kewirausahaan terhadap tugas dan pekerjaannya, baik ketepatan terhadap waktu, kualitas pekerjaan, sistem kerja, dan sebagainya.

2. Komitmen tinggi, dimana seorang wirausahawan yang teguh menjaga komitmennya kepada konsumen akan memiliki nama baik di mata konsumen, serta mendapat kepercayaan dari konsumennya.

3. Jujur, seorang wirausahawan harus jujur dalam hal karakteristik produk, mengenai promosi yang dilakukan, serta pelayanan purnajual yang dijanjikan.

4. Kreatif, seorang wirausahawan harus memiliki daya kreatif yang tinggi untuk menciptakan produk terbaru sehingga mampu memiliki daya tahan yang kuat dalam persaingan bisnis.

5. Mandiri, wirausahawan yang mandiri dapat melakukan keinginan dengan baik tanpa adanya ketergantungan pihak lain dalam mengambil keputusan atau bertindak.

Dapat disimpulkan bahwa manusia yang bersikap mental wiraswasta setidak-tidaknya memiliki enam kekuatan mental yang mengembangkan kepribadian yang kuat yaitu berkemauan keras, berkeyakinan atas kekuatan pribadi, kejujuran dan tanggung jawab, ketahanan psikis dan mental, keterampilan wiraswasta, keterampilan dalam bergaul antar manusia.

Motivasi merupakan dorongan atau menggerakkan.Pentingnya motivasi karna motivasi adalah hal yang menyebabkan, menyalurkan, dan mendukung perilaku manusia, supaya mau bekerja giat dan antusias mencapai hasil yang optimal. Menurut Hasibuan (2007), motivasi adalah pemberian daya penggerak yang menciptakan kegairahan kerja seorang agar mereka mau bekerja sama, bekerja efektif, dan terintegritas dengan segala daya upayanya untuk mencapai kepuasan.

Motivasi merupakan suatu kekuatan yang ada dalam diri kita untuk menggapai keberhasilan dari sebuah tujuan. Hal ini dipertegas Agustian (2001) bahwa kekuatan pikiran bawah sadar yang merupakan sugesti, adalah sebuah energi dahsyat yang sekaligus sebagai pilot di dalam diri kita. "Kekuatan energi akan mengalir dan akan membakar semangat Anda.Tetapkan kemauan Anda.Bedakan antara kemauan biasa dengan kemauan yang membara.Rahasia untuk sebuah keberhasilan adalah terus menerus mengingat bahwa, anda lebih baik dari yang anda pikirkan.Keberhasilan tidak memerlukan kecerdasan yang luar biasa.Keberhasilan tidak disebabkan oleh keberuntungan.Keberhasilan ditentukan oleh ukuran dari keyakinan anda untuk meraih kemenangan.Kesuksesan juga ditentukan ukuran pemikiran dan cita-cita seseorang.Bercitacitalah setingginya."

Sebagai seorang wirausaha harus memiliki motivasi meskipun dengan sikap yang berbeda-beda.Motivasi diartikan sebagai sumber penggerak bagi wirausaha untuk melakukan tindakan agar tujuan dan harapan dapat tercapai.Wanto (2014) menjelaskan bahwa motivasi berwirausaha merupakan tingkah laku yang berasal dari dalam diri seseorang untuk bergerak mengambil sebuah tindakan dalam pencapaian tujuan wirausahawan.

Motivasi adalah suatu dorongan dari dalam diri seseorang yang mendorong orang tersebut untuk melakukan sesuatu, termasuk menjadi young entrepreneur (Sarosa, 2005).Seseorang yang berhasil di dunia ini mempunyai motivasi yang kuat yang mendorong tindakan-tindakan mereka.Seorang pengusaha yang berhasil mengetahui bahwa motivasi sangat penting dan seorang pengusaha memelihara dan menjaga agar tentap terjaga motivasinya.Baum, Frese, and Baron (2007) menjelaskan bahwa motivasi dalam kewirausahaan meliputi motivasi yang diarahkan untuk mencapai tujuan kewirausahaan, seperti tujuan yang melibatkan pengenalan dan eksploitasi terhadap peluang bisnis.Motivasi yang harus dilakukan untuk pengembangan usaha baru diperlukan bukan hanya oleh rasa percaya diri dalam hal kemampuannya untuk berhasil, namun juga oleh kemampuannya dalam mengakses informasi mengenai peluang kewirausahaan.

Seorang pengusaha merupakan seorang yang menggabungkan sumber daya, tenaga kerja, bahan baku, serta aset lain untuk menghasilkan nilai yang lebih besar dari sebelumnya, juga seorang yang mengenalkan perubahan, inovasi, dan tantangan baru. Hisrich (2001) mengemukakan bahwa kewirausahaan diartikan sebuah proses dinamis dalam menciptakan tambahan kekayaan oleh 
individu yang menanggung risiko utama dalam hal modal waktu, dan/atau komitmen karier atau menyediakan nilai bagi beberapa produk atau jasa. Produk atau jasa mungkin dapat terlihat unik ataupun tidak, tetapi dengan berbagi cara nilai akan dihasilkan oleh seseorang pengusaha dengan menerima dan menempatkan keterampilan dan sumber daya yang dibutuhkan.

Hisrich (2001) menjelaskan lagi bahwa kewirausahaan (entrepreneurship) adalah proses penciptaan sesuatu yang baru pada nilai menggunakan waktu dan upaya yang diperlukan, menanggung risiko keuangan, fisik, serta risiko sosial yang mengiringi, menerima moneter yang dihasilkan, serta kepuasan dan kebebasan pribadi.

Definisi kewirausahaan menekankan empat aspek dasar menjadi seorang pengusaha: 1) Melibatkan proses penciptaan dan menciptakan suatu nilai baru 2) Menuntut sejumlah waktu dan upaya yang dibutuhkan 3) Melibatkan seseorang menjadi pemilik usaha dan penghargaan yang paling penting adalah kebebasan, lalu kepuasan pribadi, 4) Pengusaha akan merespon dan menciptakan perubahan melalui tindakan. Tindakan kewirausahaan menyatu pada perilaku sebagai bentuk tanggapan atas keputusan yang didasarkan pada pertimbangan ketidakpastian mengenai peluang untuk mendapatkan keuntungan.

Zuhal (2008) menjelaskan bahwa perubahan membutuhkan individu-individu yang menghargai hal-hal baru, berani mengambil inisiatif untuk mewujudkannya.Individu-individu tersebut adalah para wirausaha yang mampu melihat peluangpeluang usaha dari teknologi baru dan siap memecahkan segala rintangan yang menghalangi terwujudnya perubahan.Sumardi (2007) menjelaskan bahwa pengusaha atau wirausahawan (entrepreneur) merupakan seseorang yang menciptakan sebuah usaha atau bisnis yang diharapkan dengan risiko dan ketidakpastian untuk memperoleh keuntungan dan mengembangkan bisnis dengan cara membuka kesempatan kerja.Sedangkan menurut Zimmerer dan Scarborough (2008), kewirausahaan adalah suatu kemampuan kreatif dan inovatif dalam menciptakan sesuatu yang baru dan berbeda yang dijadikan dasar, kiat dan sumber daya, proses, dan perjuangan untuk menciptakan nilai tambah barang dan jasa yang dilakukan dengan keberanian menghadapi risiko dalam usaha atau perbaikan hidup untukmencari peluang menuju sukses.

Kewirausahaan merupakan program yang sangat dibutuhkan untuk melahirkan generasi masa depan yang berkualitas dan mampu menghadapi perubahan zaman. Dengan kewirausahaan mahasiswa tidak hanya pintar secara akademik, tetapi memiliki keterampilan dalam memimpin, mengelola tim dan usaha, memiliki mental yang kuat, kreatif dan inovatif, dan memiliki daya saing yang tinggi.

Menurut Siswoyo (2009) program kewirausahaan mampu mengatasi permasalahan pengangguran terdidik dari kalangan mahasiswa.Program kewirausahaan yang dikemas baik akademik maupun diluar akademik, mampu menumbuhkan jiwa positif dan kuat seperti tangguh, ulet, dan mandiri.

Niat kewirausahaan merupakan variable penting untuk memprediksi perilaku kewirausahaan. Niat kewirausahaan dapat diartikan sebagai langkah awal dari suatu proses pendirian sebuah usaha yang umumnya bersifat jangka panjang Lee dan wong, (2004). Berdasarkan berbagai penelitian yang telah dilakukan terhadap minat (intensi) mahasiswa dapat disimpulkan bahwa minat (intensi) kewirausahaan seseorang dipengaruhi oleh sejumlah faktor yang dapat dilihat dalam kerangka yang terintegrasi yang keterlibatan dari berbagai faktor internal, faktor eksternal, dan faktor kontekstual.Faktor internal berasal dari diri wirausahawan dapat berupa karakter sifat, maupun faktor sosio demografis, seperti umur, jenis kelamin, dan lain-lain yang dapat mempengaruhi perilaku kewirausahaan seseorang (Nishanta, 2008).Sedangkan faktor eksternal berasal dari luar diri pelaku entrepreneur yang dapat berupa unsur dari lingkungan sekitar misalnya dukungan dari orang tua, teman, dan sebagainya.

Untuk mengembangkan jiwa kewirausahaan tersebut dibutuhkan usaha-usaha terprogram dan terukur, sehingga berdampak langsung pada kehidupan nyata mahasiswa. Adapun usaha atau strategi untuk mengembangkan jiwa kewirausahaan antara lain :

1. Inkubator menurut keputusan menteri negara koperasi dan UKM Republik Indonesia nomor 81.2/kep/M.KUKM/VIII/2002 adalah lembaga yang bergerak dalam bidang penyediaan fasilitas dan pengembangan usaha, baik manajemen maupun teknologi bagi UMK untuk meningkatkan usahanya dan mengembangkan kegiatan usaha atau pengembangan produk baru agar dapat berkembang menjadi wirausaha yang tangguh dan atau produk baru yang berdaya saing dalam jangka waktu tertentu.Penelitian yang dilakukan oleh Suratna (2008), menemukan bahwa Model Inkubator bisnis memiliki efek positif yang signifikan terhadap jiwa kewirausahaan. Namun demikian tidak 
semua aspek terjadi peningkatan. Aspek yang meningkat secara sinifikan adalah kepemimpinan,kemandirian, kerja sama, motivasi, dan orientasi bisnis

2. Pusat studi kewirausahaan kampus seperti koperasi mahasiswa, community entrepreneur program, dan lain sebagainya

3. Mata kuliah kewirausahaan dan menyisipkan semangat kewirausahaan di setiap perkuliahan. Menurut Siswoyo (2009), Kuliah kewirausahaan umumnya hanya bagi fakultas/jurusan tertentu saja. Tidak semua jurusan mempunyai cara pandang yang sama untuk mengalokasikan SKS guna menyajikan matakuliah ini. Masih sebuah kesepakatan dan kesamaan pandang tentang perlunya disajikan kuliah kewirausahaan di semua jurusan/prodi yang ada. Kemudian pelaksanaan mata kuliah ini dapat melibatkan team teaching sehingga mahasiswa akan mendapatkan wawasan dan pengalaman yang kaya.

4. Event-event wirausaha baik pemerintah maupun swasta.

5. Komunitas bisnis.

6. Pengembangan diri melalui membaca, berdiskusi, pelatihan dan seminar bisnis, coaching bisnis dan lain sebagainya

Strategi atau usaha pengembangan jiwa kewirausahaan di atas perlu disosialisasikan secara berkesinambungan, sehingga mahasiswa termotivasi dan mampu membangun jiwa kewirausahaan lebih baik.

\section{METODOLOGI PENELITIAN}

Dalam penelitian ini, peneliti ingin memperoleh data yang mendalam secara alami tentang proses pengembangan jiwa kewirausahaan yang terjadi di lapangan. Data penelitian yang diperoleh berupa kata-kata dan akan dipaparkan sesuai dengan kejadian yang terjadi dalam penelitian. Selain itu kehadiran peneliti mutlak diperlukan. Sesuai dengan karakteristik yang dikemukakan di atas maka pendekatan penelitian ini adalah pendekatan kualitatif, dikarenakan (1) peneliti bertindak sebagai instrumen utama, disamping pengumpul data dan penganalisis data, peneliti juga terlibat langsung dalam proses penelitian, (2) mempunyai latar alami, (natural setting), data yang diteliti dan dihasilkan akan dipaparkan sesuai dengan yang terjadi dilapangan, (3) hasil penelitian bersifat deskriptif, karena data yang dikumpulkan bukan berupa angkaangka melainkan berupa kata-kata, (4) lebih mementingkan proses daripada hasil, (5) adanya batas permasalahan yang ditentukan dalam fokus penelitian, dan (6) analisis data cenderung bersifat induktif.

Mengacu kepada data penelitian ini bersifat kualitatif dimana data yang disajikan dalam bentuk kata verbal bukan dalam bentuk angka.Mengacu pada penjelasan di atas, maka untuk menentukan informan dalam penelitian ini, peneliti menggunakan teknik purposive sampling dimana untuk menentukan sampel penelitian dengan beberapa pertimbangan tertentu yang bertujuan agar data yang diperoleh nantinya bisa lebih representatif.

Data yang dikumpulkan dalam penelitian ini berupa data wawancara, dokumentasi, observasi dan catatan lapangan yang diperoleh dari informan.Informan dalam penelitian ini adalah dosen kewirausahaan, narasumber pelatihan, pimpinan dan teman sejawat mahasiswa. Sedangkan subjek dari penelitian ini adalah mahasiswa Semester tiga Kuliah Kewirausahaan Politeknik Kridatama Bandung yang berjumlah 98mahasiswa dengan rincian sebagai berikut:

\begin{tabular}{cccc}
\multicolumn{5}{c}{$\begin{array}{c}\text { Tabel 2 } \\
\text { Jumlah Mahasiswa Politeknik Kridatama } \\
\text { Tahun Akademik 2018/2019 } \\
\text { Po }\end{array}$} & $\begin{array}{c}\text { Semester } \\
\text { Studi }\end{array}$ & $\begin{array}{c}\text { Jumlah } \\
\text { Mahasiswa }\end{array}$ \\
\hline 1. & III & $\begin{array}{c}\text { Manajemen } \\
\text { Informatika }\end{array}$ & 28 \\
\hline 2. & III & Administrasi Bisnis & 50 \\
\hline 3. & III & $\begin{array}{c}\text { Penyiaran Radio dan } \\
\text { Televisi }\end{array}$ & 20 \\
\hline & & & $\mathbf{9 8}$ \\
\hline
\end{tabular}

Sumber: BagianAkademik Politeknik Kridatama, 2018

Untuk pemeriksaan keabsahan data setelah kaitan antara kategori dan pola data dengan asumsi terwujud, peneliti masuk ke dalam tahap penjelasan. Dan berdasarkan kesimpulan yang telah didapat dari kaitannya tersebut, peneliti merasa perlu mencari suatu alternatif penjelasan lain tentang kesimpulan yang telah didapat. Sebab dalam penelitian kualitatif memang selalu ada alternatif penjelasan yang lain. Dari hasil analisis, ada kemungkinan terdapat hal-hal yang menyimpang dari asumsi atau tidak terpikir sebelumnya. Pada tahap ini akan dijelaskan dengan alternatif lain melalui referensi atau teori-teori lain. Alternatif ini akan sangat berguna pada bagian pembahasan, kesimpulan dan saran.

Teknik pengumpulan data menggunakan pendekatan penelitian kualitatif meliputi:

1. Wawancara.

Wawancara digunakan sebagai teknik pengumpulan data, apabila peneliti ingin 
melakukan pendahuluan untuk menentukan permasalahan yang harus diteliti, dan juga apabila peneliti ingin mengetahui hal-hal dari responden yang lebih mendalam dan jumlah respondennya sedikit/kecil.Teknik pengumpulan data berdasarkan pada laporan diri sendiri (self report) atau setidak-tidaknya pada pengetahuan dan keyakinan pribadi. Teknik interview digunakan dalam melakukan tanya jawab secara mendalam dengan para responden. Wawancara dilakukan dengan tujuan untuk mendapatkan keterangan atau pendirian lisan dari responden, menyangkut pendirianpendiriannya. Hasil wawancara dicatat dalam catatan sementara hasil wawancara, pada akhirnya disusun kembali transkip wawancara.

2. Dokumentasi

Teknik dokumentasi digunakan karena dalam banyak hal dokumen dapat dimanfaatkan untuk menguji, menafsir bahkan meramalkan, dilakukan bahan-bahan tertulis berupa arsip dan dokumen disamping itu, ada beberapa alasan dari penggunaan dokumentasi antara lain: dokumen dan recorder merupakan sumber yang stabil, kaya dan mendorong, berguna sebagai bukti untuk suatu kejadian, memiliki sifat alamiah, sesuai dengan konteks, lahir dan berada dalam konteks serta mudah dan tidak sukar diperoleh. Adapun dokumentasi yang dilakukan oleh peneliti dilokasi penelitian antara lain mendokumentasikan alur. Data merupakan bahan penting yang berguna untuk permasalahan yang terjadi. Data yang dijadikan adalah informasi yang ada kaitannya dengan penelitian.

3. Studi Pustaka

Studi ini dapat diartikan sebagai suatu langkah untuk memperoleh informasi dari penelitian terdahulu yang harus dikerjakan, tanpa memperdulikan apakah sebuah penelitian menggunakan data primer atau data sekunder, apakah penelitian tersebut menggunakan penelitian lapangan ataupun laboratorium atau di dalam ruangan. Nazir (2011) menjelaskan studi kepustakaan adalah teknik pengumpulan data dengan mengadakan studi penelaahan terhadap buku-buku, literatur-literatur, catatan-catatan, dan laporan-laporan yang ada hubungannya dengan masalah yang dipecahkan.

Analisis data yang digunakan peneliti menggunakan model Miles and Huberman. Analisis data dalam penelitian kualitatif, dilakukan pada saat pengumpulan data berlangsung, dan setelah selesai pengumpulan data dalam periode tertentu. Pada saat wawancara, peneliti sudah melakukan analisis terhadap jawaban yang diwawancarai.Miles and Huberman mengemukakan bahwa aktivitas dalam analisis data kualitatif dilakukan secara interaktif dan berlangsung secara terus menerus sampai tuntas, sehingga datanya sudah jenuh. Aktivitas dalam analisis data yaitudata reduction, data display, dan conclusion drowing/verification.

Proses reduksi data berupa penyempurnaan data sikap dan pengembangan jiwa kewirausahaan mahasiswa Poltek Kridatama Bandung, baik pengurangan terhadap data yang dianggap kurang perlu dan tidak relevan, maupun penambahan data yang dirasa masih kurang guna menyempurnakan data tentang jiwa kewirausahaan dan pengembangan jiwa kewirausahaan mahasiswa Poltek Kridatama Bandung

Langkah selanjutnya dalam analisis data adalah dengan mendisplay atau menyajikan data yang akan memudahkan peneliti untuk memahami apa yang terjadi selama penelitian berlangsung. Penyajian data merupakan proses pengumpulan informasi yang disusun berdasarkan kategori atau pengelompokanpengelompokan yang diperlukan peneliti agar penyajian data bisa berbentuk uraian singkat, bagan, hubungan antar kategori flowchart tentang sikap dan pengembangan jiwa kewirausahaan mahasiswa Poltek Kridatama Bandung

Dalam analisis data, peneliti menggunakan model interactive model, yang unsur-unsurnya meliputi reduksi data (data reduction), penyajian data (data display), dan conclutions drowing/verifiying. Alur teknik analisis data sebagai berikut:

1. Reduksi Data

Pengertian dari reduksi data yaitu proses penyempurnaan data, baik pengurangan terhadap data yang dianggap kurang perlu dan tidak relevan, maupun penambahan data yang dirasa masih kurang. Data yang di hasilkan di lapangan mungkin jumlahnya sangat banyak.Reduksi data berarti merangkum, memilih hal-hal yang pokok, memfokuskan pada hal-hal yang penting, dicari tema dan polanya. Dengan demikian data yang akan direduksi memberikan gambaran yang lebih jelas, dan mempermudah peneliti untuk melakukan pengumpulan data selanjutnya, dan mencarinya bila diperlukan (Sugiyono, 2016). 
2. Penyajian Data

Penyajian data yaitu mendisplay atau menyajikan data akan memudahkan untuk memahami apa yang terjadi selama penelitian berlangsung. Setelah berlangsung perlu adanya perencanaan kerja berdasarkan apa yang telah dipahami. Dalam penyajian data selain menggunakan teks secara naratif, juga dapat berupa bahasa nonverbal seperti bagan, grafik, denah, matriks, dan tabel. Penyajian data yaitu merupakan proses pengumpulan informasi yang disusun berdasarkan kategori atau pengelompokan-pengelompokan yang diperlukan. Miles and Huberman dalam penelitian kualitatif penyajian data bisa dilakukan dalam bentuk uraian singkat, bagan, hubungan antar kategori flowchart dan sejenisnya.

3. Penarikan Kesimpulan

Penarikan kesimpulan yaitu Langkah terakhir yang digunakan teknik analisis data adalah verifikasi data. Verifikasi data dilakukan apabila kesimpulan awal yang dikemukan masih bersifat sementara, dan akan ada perubahan-perubahan bila tidak dibarengi dengan bukti-bukti pendukung yang kuat untuk mendukung pada tahap pengumpulan data berikutnya. Bila kesimpulan yag dikemukan pada tahap awal, didukung dengan bukti-bukti yang valid dan konsisten saat penelitian kembali ke lapangan mengumpulkan data, maka kesimpulan yang dikemukan merupakan kesimpulan yang kredibel atau dapat dipercaya. (Sugiyono, 2016).

Langkah terakhir dalam analisis model Miles and Huberman yaitu penarikan kesimpulan yang dilakukan peneliti apabila kesimpulan awal yang dikemukan masih bersifat sementara, dan akan ada perubahan-perubahan bila tidak dibarengi dengan bukti-bukti pendukung yang kuat untuk mendukung pada tahap pengumpulan data berikutnya tentang sikap dan pengembangan jiwa kewirausahaan mahasiswa Poltek Kridatama Bandung

\section{HASIL DAN PEMBAHASAN}

Mahasiswa Politeknik Kridatama Bandung yang memiliki sikap mental wiraswasta berkemauan keras untuk berwiraswasta dengan mengikuti perkuliahan kewirausahaan dan beberapa pelatihan yang diadakan di kampus Politeknik Kridatama Bandung.Setelah mengikuti perkuliahan dan pelatihan-pelatihan mahasiswa antusias untuk berwirausaha dan berkeyakinan atas kekuatan pribadi bahwa mahasiwa Politeknik Kridatama bisa melakukan kegiatan wirausaha yang dapat dilakukan di dalam ataupun di luar kampus.Sebagai wirausahawan diperlukan kejujuran dan tanggung jawab untuk kelangsungan produk atau jasa yang dijalankan.Selain itu, diperlukan juga ketahanan psikis dan mental untuk mempromosikan produk dan jasa yang mahasiswa buat. Produk dan jasa yang mahasiswa buat tidak hanya memerlukan hal-hal yang sudah disebutkan di atas namun juga keterampilan wiraswasta yang dapat diperoleh dari perkuliahan, pelatihan-pelatihan dan informasiinformasi tentang kewirausahaan yang bisa mahasiswa dapatkan melalui website, media sosial serta seminar-seminar dan pelatihan-pelatihan di luar kampus sehingga keterampilan dalam bergaul antar manusia juga dapat terjalin dengan baik. Seorang wirausahawan yang sukses mampu berpikir dan bertindak kreatif serta inovatif, bekerja tekun dan produktif, mampu berkarya berlandaskan etika bisnis yang sehat dan mampu memecahkan masalah yang kemudian mengambil keputusan secara sistematis.Tujuan-tujuan tersebut sebagian besar telah tercapai dengan sikap mahasiswa Politeknik Kridatama yang telah terbentuk dari adanya pertama keterampilan dasar yang membentuk sikap mental dan spiritual tinggi, membentuk kepribadian unggul yang pandai berinisiatif dan dapat mengkoordinasikan kegiatan usahanya.Kedua keterampilan khusus yang mana keterampilan melakukan kegiatan usaha secara menyeluruh berdasarkan konsep yang telah dibuat mahasiwa.Jadi menjalankan kegiatan usaha sesuai dengan rencana yang telah dibuat untuk mencapai tujuan-tujuan dalam pemenuhan kebutuhan dalam kehidupan.

Sesuai dengan pernyataan (Rosmiati, 2015) Sikap (attitude) adalah perasaan, pikiran, dan kecenderungan seseorang yang kurang lebih bersifat permanen mengenal aspek-aspek tertentu dalam lingkungannya.Sikap merupakan kesiapan mental atau emosional dalam beberapa jenis tindakan pada sesuatu yang tepat. Selain itu dapat diartikan sebagai sesuatu yang dipelajari dan bagaimana individu bereaksi terhadap situasi dan menentukan apa yang dicari dalam kehidupan.

Untuk mengembangkan usaha baru mahasiswa diperlukan rasa percaya diri dalam hal kemampuannya untuk berhasil dan kemampuannya dalam mengakses informasi mengenai peluang kewirausahaan.Semakin banyaknya pengangguran, memaksa seseorang untuk bisa lebih kreatif dalam memenuhi kebutuhan hidupnya.Salah satu jalan untuk mengurangi pengangguran tersebut yaitu dengan berwirausaha.Membangkitkan jiwa 
wirausaha mahasiswa dengan motivasi yang berasal dari dalam atau pun dari luar, karena tidak mudah untuk mendorong seorang mahasiwa untuk mau berkecimpung di dunia wirausaha. Mayoritas mahasiswa banyak ketakutan untuk memulai usaha dan ketakutan akan rugi dalam kegiatan berwirausaha yang penyebab utamanya adalah kurangnya motivasi untuk berwirausaha. Motivasi merupakan kunci yang akan membuka potensi mahasiswa untuk berwirausaha sehingga potensi yang dimiliki akan menjadi kemampuan yang dahsyat. Motivasi untuk berwirausaha salah satu pendorong tumbuh kembangnya jiwa wirausaha mahasiswa, karena kesuksesan mahasiswa seringkali disertai dengan motivasinya yang kuat dalam menjalankan setiap usaha yang sedang dilakukan.

Salah satu motivasi yang paling diperlukan calon atau pelaku usaha yaitu keinginan untuk terus belajar dan menambah keterampilan.Motivasi belajar menjadi modal awal bagi para calon dan pengusaha untuk mengembangkan bisnisnya.Oleh karena itu, belajar dari orang-orang sukses di sekitar lingkungan mahasiwa Politeknik Kridatama sangatlah diperlukan untuk membangkitkan motivasi.Langkah yang tepat sekali jika metode paksaan dengan mengikuti perkuliahan, seminar-seminar dan pelatihanpelatihan kewirausahaan dilaksanakan secara kontinue di dalam atau di luar kampus.Kegiatankegiatan tersebut, dapat memotivasi mahasiswa terdorong untuk berbuat dan melakukan sesuatu yang diinginkan.Motivasi dalam berwirausaha memang sangat diperlukan guna menjalankan suatu usaha untuk memulai dan memajukan usahanya. Dengan adanya motivasi yang berasal dari dalam dan luar, akanmemudahkan mahasiswa untuk memulai dan menjalankan usaha apapun karena motivasi merupakan modal awal yang harus dimiliki dan dikembangkan oleh seorang wirausahawan. Tanpa adanya motivasi mustahil suatu usaha dapat berjalan sendiri tanpa ada yang menggerakkannya.
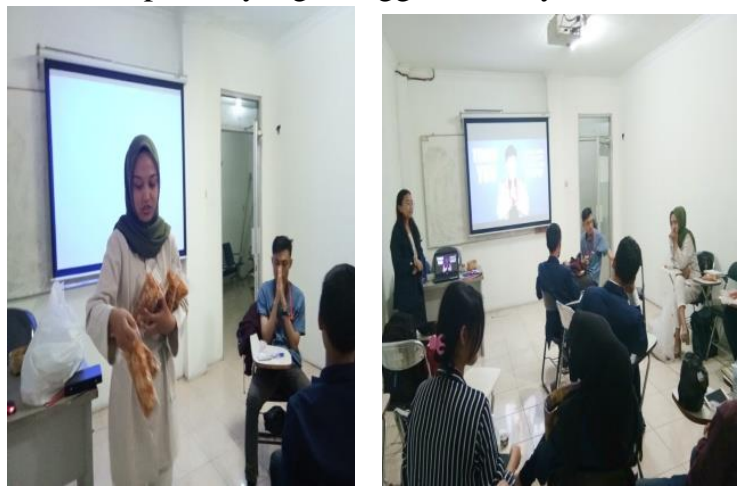

Gambar 1 Presentasi Hasil Usaha
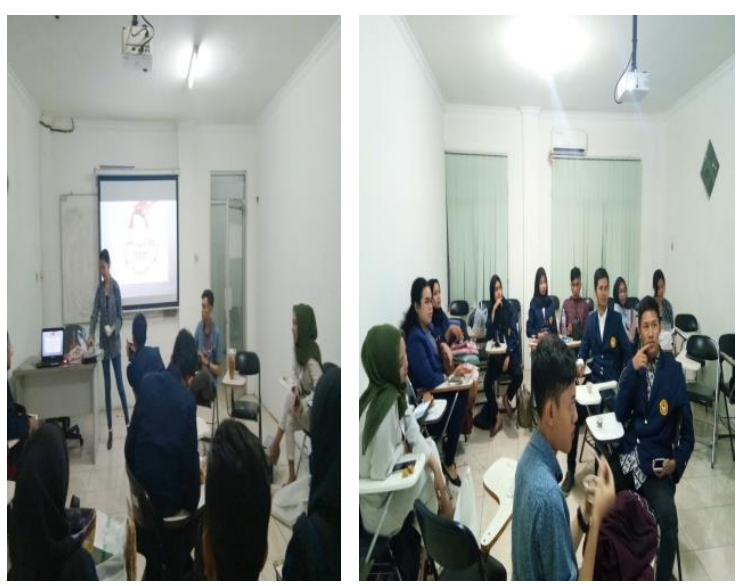

Gambar 2 Presntasi Hasil Usaha

Sesuai dengan pernyataan (Sarosa, 2005) Motivasi adalah suatu dorongan dari dalam diri seseorang yang mendorong orang tersebut untuk melakukan sesuatu, termasuk menjadi young entrepreneur.

Pengembangan jiwa kewirausahaan akan berdampak pada penguatan perilaku kewirausahaan dan peningkatan perilaku kewirausahaan. Pengembangan tersebut akan membentuk kemandirian usaha yang berarti calon pelaku usaha akan memiliki jiwa usaha dan pelaku usaha kecil akan meningkatkan usahanya.

Kewirausahaan merupakan pilihan yang dianggap potensial untuk dikembangkan, karena banyak fakta di sekitar tokoh-tokoh wirausaha yang telah banyak memberikan kontribusi pada pertumbuhan ekonomi dan sosial.Jiwa wirausaha mempunyai kekuatan ingin maju, berkembang dan mandiri.Para pengusaha telah memberikan kontribusi pada kemajuan ekonomi dan sosial bangsa serta memberikan lapangan pekerjaan untuk mengurangi pengangguran.Untuk pengembangan jiwa kewirausahaan pemerintah sudah memberikan kesempatan pada berbagai pihak baik melalui pendidikan formal maupun pendidikan non formal. Dalam pendidikan formal pemerintah memasukkan mata kuliah kewirausahaan dan program-program hibah yang ditawarkan untuk perguruan tinggi demi pengembangan kewirausahaan bagi mahasiswa.Sedangkan kegiatan pendidikan non formal dengan mengadakan berbagai kursus pelatihan-pelatihan dan seminar-seminar kewirausahaan untuk membentuk dan mengembangkan jiwa kewirausahaan.

Sesuai dengan pendapat (Siswoyo, 2009) program kewirausahaan mampu mengatasi permasalahan pengangguran terdidik dari kalangan 
mahasiswa.Program kewirausahaan yang dikemas baik akademik maupun diluar akademik, mampu menumbuhkan jiwa positif dan kuat seperti tangguh, ulet, dan mandiri.

Dan pendapat tersebut diperkuat dengan teori menurut (Nishanta, 2008) Faktor internal berasal dari diri wirausahawan dapat berupa karakter sifat, maupun faktor sosio demografis, seperti umur, jenis kelamin, dan lain-lain yang dapat mempengaruhi perilaku kewirausahaan seseorang karena sikap dapat dipengaruhi oleh sifat yang ada dalam diri seseorang. Sifat tersebut dapat berorientasi pada perkembangan yang sangat diperlukan oleh seorang wirausahawan agar sukses memiliki usaha yang maju dan berkembang.

Berdasarkan informasi yang di dapat dari Politeknik Kridatama Bandung mahasiswa sudah sebagian memiliki usaha dan menjadi reselleryaitu sebagai berikut :

Tabel 1 Produk-Produk Yang Dihasilkan

Pemilik usaha Veny
Fitriani produk bakso
instan lada yang di jual
melalui media sosial
dengan akun instgram
@balada_baksoinstanlada

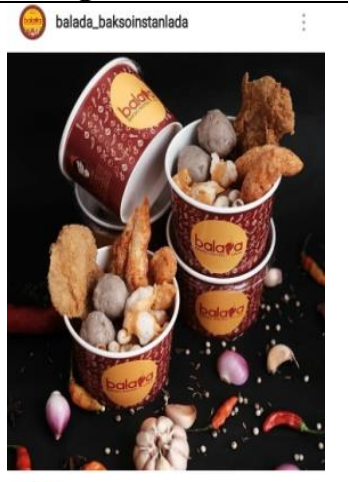

Reseller mahasiswa semester III atas nama Nada Alya Fikri bakso urat bom dijual melalui online dan membuka tempat di jalan Sanding bawah No 108 Garut

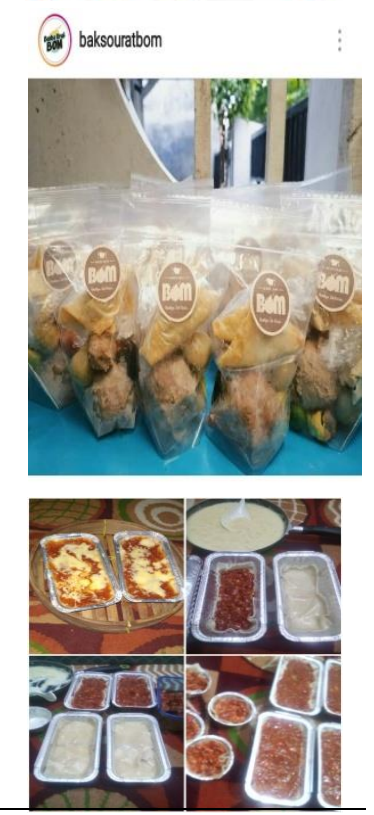

Dengan nama sebutan Cipuk bu haji (Cipuk Kekinian) yg di jual dengan mengunakan media sosial mahasiswa winda

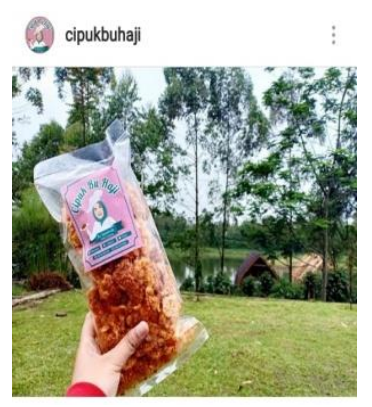

Jasa Photography dengan akun instgram @lynxxpho pemilik mahasiswa septian primal jurusan penyiaran radio $\&$ televise

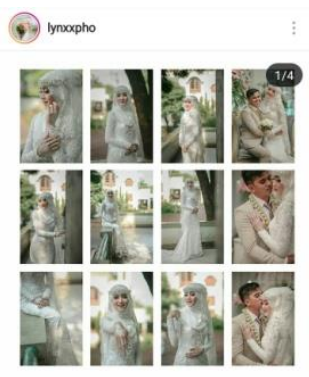

LYNXX PHOTOGRAPHY

Combrella (combrok isi mozzarella) yang di jual melalui terima pesanan yaitu pemilik mahasiswa ganjar semester III

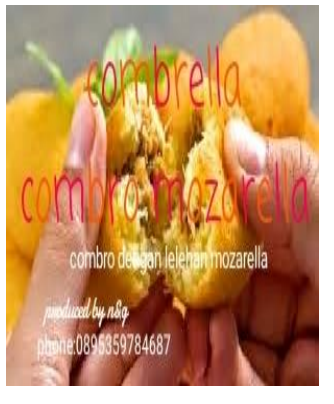

Dampak pada penguatan perilaku kewirausahaan dan peningkatan perilaku kewirausahaan. Pengembangan tersebut akan membentuk kemandirian usaha yang berarti calon pelaku usaha akan memiliki jiwa usaha dan pelaku usaha kecil akan meningkatkan usahanya.

Dari hasil yang diperoleh mahasiswa Politeknik Kridatama masih membutuhakan banyak pelatihan tentang kewirausahaan, seminar kewirausahaan dan masih belum percaya diri karena belum memiliki produk yang akan dikembangkan masih bingung harus bagaimana memulai usaha mahasiswa Politeknik Kridatama Bandung masih membutuhkan banyak informasi-informasi untuk pengembangan jiwa kewirausahaan. Namun, sebagian besar telah tercapai memiliki produk yang dikatakan diminati oleh pelangan dengan sikap mahasiswa Politeknik Kridatama yang telah terbentuk dari adanya pertama keterampilan dasar yang membentuk sikap mental, membentuk kepribadian unggul yang pandai 
berinisiatif dan dapat mengkoordinasikan kegiatan usahanya.

\section{KESIMPULAN}

Berdasarkan hasil pembahasan bahwa Mahasiswa Politeknik Kridatama Bandung belum memiliki sikap percaya diri sehingga dibutuhkan motivasi dan pengembangan jiwa kewirausahaan. Dengan adanya motivasi yang berasal dari dalam dan luar, akan memudahkan mahasiswa untuk memulai dan menjalankan usaha. Dari hasil wawancara dosen kewirausahaan mahasiswa Politeknik Kridatama membutuhakan banyak pelatihan tentang kewirausahaan, seminar kewirausahaan dan mahasiswa Politeknik Kridatama Bandung masih membutuhkan banyak informasi-informasi untuk pengembangan jiwa kewirausahaan.Pengembangan tersebut akan membentuk kemandirian usaha yang berarti calon pelaku usaha akan memiliki jiwa usaha dan pelaku usaha kecil akan meningkatkan usahanya.

\section{REFERENSI}

Agustian, Ary Ginanjar (2001) Rahasia Sukses Membangun Kecerdasan Emosional dan Spiritual. Jakarta: Arga.

Baum, J. R., Frese, M., \& Baron, R. A. (2007).The psychology of entrepreneurship. Mahwa, New Jersey: Lawrence Erlbaum Associates.

Hasibuan, H, Malayu S.P. (2007). Manajemen Sumber Daya Manusia. Jakarta: Bumi Aksara.

Hisrich, R. (2001). Entrepreneurship kewirausahaan. Jakarta: Salemba Empat.

Kamus Besar Bahasa Indonesia (KBBI)

Lee, S.H. dan Wong, P.K. (2004) . An Exploratory Study of Technopreneurial Intentions: A Career Anchor Perspective, Journal of Business Venturing, 19 (1), 7-28

Moleong, Lexy, (2002) Metodologi Penelitian Kualitatif, PT. Remaja Rosdakarya, Bandung, .

Nazir, Mohammad, (2011). Metode Penelitian. Jakarta: Ghalia Indonesia.

Nishanta, B. (2008). Influence of Personality Traits and Socio-demographic Background of Undergraduate Student and Motivation for Entrepreneurial Career : The Case of Srilangka. Paper was presented at the EuroAsia Management Studies Association (EAMSA) Conference, Japan.

Rosmiati, dkk. (2015). Sikap, Motivasi, dan Minat Berwirausaha Mahasiswa. Jurnal. Akuntansi Politeknik Negeri Kupang. Kupang.

Saifudin, Azwar. (2005). Sikap Manusia. Yogyakarta: Pustaka Belajar.
Sarosa, P. (2005). Kiat praktis membuka usaha. Becoming young entrepreneur: Dream big start small, act now! Panduan praktis \& motivasional bagi kaum muda dan mahasiswa. Jakarta: PT Elex Media Komputindo.

Siswoyo, Bambang, B. (2009). Pengembangan Jiwa Kewirausahaan di Kalangan Dosen dan Mahasiswa.Jurnal Ekonomi Bisnis Fakultas Ekonomi Universitas Negeri Malang.

Sugiyono, (2012). Memahami Penelitian Kualitatif. Bandug:Alfabeta.

Sugiyono, (2016). Memahami Penelitian Kualitatif. Bandug:Alfabeta.

Suharyadi, Nugroho. A., Purwanto.,\& Maman. F. (2007). Kewirausahaan Membangun Usaha Sukses Sejak usia Muda. Jakarta: Salemba Empat.

Sumardi, K (2007).Menakar jiwa wirausaha mahasiswa teknik mesin angkatan 2005.Jurnal Pendidikan teknologi Kejuruan, IV (10).

Soekidjo, Notoatmodjo. (2005). Metodologi Penelitian Kesehatan. Jakarta: Rineka Cipta.

Wanto, F. Sakti. (2014). Hubungan Kemandirian dan Motivasi Berwirausaha dengan Minat Berwirausaha Siswa Kelas XI SMKN 1 SEYEGAN.Skripsi. UNY: Yogyakarta.

Zimmerer, T. W., and Scarborough, N.M., Wilson, D. (2008). Essential of Entrepreneurship and Small Business Management, 5th Ed . New Jersey, Pearson Education, Inc.

Zuhal, Muh.,(2008). Relasi Pondok Pesantren dengan Madrasah Negeri; Studi Kasus PP. Miftahul 'Ula Nglawak Kertosono Nganjuk, Kediri: Tesis Tidak Diterbitkan,.

\section{PROFIL PENULIS}

Evi Selvi, SE., MM Dosen Tetap Universitas Singaperbangsa Karawang Lulusan S1 Universitas Sanggabuana, S2 STIE IPWI Jakarta Lulusan tahun 2014

Dewi Untari, SE., MM Pengajar di Politeknik Kridatama Bandung Lulusan S2 Universitas Winaya Mukti Lulusan tahun 2014 